\title{
A freshmen mentoring program at the Universitat Politècnica de València over the period 2000-2010
}

\author{
Xavier Barrachina ${ }^{1}, \mathrm{~J}$. Alberto Conejero ${ }^{1}$, Eloína García-Félix ${ }^{2}$ \\ ${ }^{1}$ ETS Ingeniería Informática y IUMPA - Universitat Politècnica de V alència (SPAIN); ${ }^{2}$ Instituto de \\ Ciencias de la Educación - Universitat Politècnica de V alència (SPAIN) \\ xabarci@upvnet.upv.es; aconejero@mat.upv.es; algarcia@ice.upv.es
}

Received December 2010

Accepted April 2011

\section{Abstract:}

Putpose: We quantify the dedication of mentors and mentees in a double-mentor program for freshmen. We also analyze the fulfillment of the expectations of all the participants and the utility of each mentor during the meetings.

Design/methodology/approach: A questionnaire addressed to the participants was designed and took to all of them.

Findings: We see that the mentees are highly satisfied with the mentoring program. Despite of mentors want mentees to participate more intensively in the program, mentees consider that their participation in the program is sufficient. Student and teacher mentors agree that freshmen could take more profit of the program. We also observe that the student mentor is slightly more implicated in the program than the teacher mentor.

Research limitations/implications: Our results depend on the opinion of the mentors and the mentees. It would be fruitful to know the opinion of the freshmen who are not enrolled in the program. 
Practical implications: Our research confirms the validity of the system. We hope that our conclusions will be fruitful for other institutions that would like to implement a double-mentor program for freshmen.

Originality/value: Many mentoring programs have been designed basing on a big brother/sister system. We analyze the development of a double-mentor program. The last law concerning university students, approved in Spain in 2011, indicates that mentoring programs should be designed in the frame of every degree, and they should be conducted by teachers and by technical staff. With our formula, both approaches are combined.

Keywords: freshmen, mentoring program, management education, first year programs

\section{Introduction}

In the last years, mentoring has been applied not only in professional, but also in academic environments. Mentoring can be understood as a series of specific planned actions carried out by institutions in order to enable potential learning and growth of students during their training. A review of the most significant findings of mentoring in education in contrast to business and medical mentoring can be found in (Ehrich, Hansford, \& Tennent, 2004). In the educational context, the main goal of mentoring is related to adaptation and success of the students. An improvement of the academic success is understood as higher academic marks, a higher number of passed subjects, and a lower dropout rate.

Mentoring programs are usually set in two different ways: On the one hand freshmen are assigned to experienced students (big brothers $\&$ sisters) acting as mentors. On the other hand, teachers can also act as mentors or supervisors. When senior students act as mentors, the main goal for mentoring is helping freshmen to adapt to the study environment, face course related problems and other general issues. When teachers act as mentors, a more academic approach can be obtained, however sometimes freshmen are discouraged to participate, since they are ashamed of talking to teachers in private. There are different 
surveys about mentoring programs in the academic context, see for instance (Campbell \& Campbell, 1997; Pendleton, 2006; Husband \& Jacobs, 2009).

A mentoring program for freshmen is extremely important in engineering degrees, since they meet basic subjects that assume many previous concepts, and technical subjects that are quite different in contents and methodologies from the ones taken at the High School period. PATU program (Programa de Acción Tutorial Universitario) of the Universitat Politècnica de València (UPV) was one of the first mentoring programs that were established at a university in Spain in 2000, see (García \& Cáceres, 2000; Universitat Politècnica de València, 2001), starting as an innovative teaching experience. In the following years, other programs started at the Universidad de Sevilla (Valverde, García, \& Romero, 2001) and at the Universidad Politécnica de Madrid (Sánchez, Almendra, \& Jiménez, 2007). Programs like this usually start as an innovation proposed by faculties of Psychology or Pedagogy. However, the present case is different since the UPV lacks of these faculties and most of our students are enrolled in engineering degrees. Another characteristic of this program is that it is conducted at all the schools and faculties of the university, which is not the usual situation.

Nowadays, more and more attention is paid in Spain to programs for freshmen that smooth the transition from post-compulsory secondary education to university. For references to other mentoring programs in Spanish universities see for instance (Arco et al., 2004; Arco, 2010; Casado \& Ruíz, 2009; Marchena et al., 2005; Sánchez Ávila, 2009). Furthermore, in the new law for students at Spanish universities it is indicated that universities have to develop mentoring systems coordinated with the information and guidance services, and these programs have to be conducted by teachers and guidance counselors (Boletín Oficial del Estado, 2010).

\section{Objectives}

Most of the mentoring programs carried out in Spanish universities are based on peer mentoring. Mentors are students of last years who act as big brothers and sisters. In contrast to them, in the PATU program every freshman has a student and a teacher mentor. One of the goals of our research is to assess each role in the 
program. To do this, we have asked all participants to make a peer evaluation by filling a questionnaire.

Secondly, the participation in the program of all actors is recognized. Some free credits are assigned to the mentees and the student mentors. On the other hand, some hours are assigned to the teacher mentor in the Teaching Activity Indicator of the university. According to the hours invested in the program by the students and the new accounting in terms of ECTS, we want to know what should be the suitable recognition for them.

Finally, we want to know if the expectations of the participants are fulfilled the end of the program. Our hypothesis is that the students are satisfied with the program, much more satisfied than what mentors think.

\section{Methodology and approach}

Since 2000, the program has evolved in order to try to attend to the requirements of the mentees and the suggestions of the teacher and student mentors. In May, 2009, a questionnaire was administered to all participants in the program during the academic year $2008 / 2009$. That year, the program was initially proposed to 4064 freshmen in October 2008. At that time, 1446 students $(35.58 \%$ of all freshmen) successfully finished the program. To mentor them, 347 students and 335 teachers were involved in the program. The questionnaire was administered to all of the participants. It was finally answered by 672 mentees $(46.47 \%), 174$ teacher mentors (51.9\%), and 319 student mentors (91.93\%). All of them were encouraged to answer it in order to get the recognition for their participation.

The paper is organized as follows: In Section 4 we explain how and when the program started. Later, in Section 5, we report the main characteristics of the program. We also explain how the program is organized and conducted. The roles of the teacher and student mentors, and their tasks are also detailed. Section 6, contains results concerning the dedication to the program of all participants and results of a peer evaluation between mentors and mentees. We also include a list of topics treated in the mentoring sessions. Finally, Section 7 includes some conclusions regarding the dedication and expectations of the participants in the program. We expect that the report of our experience with a double mentor, a teacher and a student, was useful to other institutions. 


\section{Origin of the PATU program}

In 2000/2001 the Vicerrectorado de Coordinación Académica y Alumnado of the UPV offered several programs for teaching innovation and for improving the learning of the students. All these programs were integrated in a general frame called the EUROPA Project (una Enseñanza Orientada al Aprendizaje - A teaching practiced focused on learning) (Universidad Politécnica de Valencia, 2001). Its main goal was to improve education from the point of view of teaching and learning. A little sooner, the necessity of reducing the transition gap from baccalaureate and vocational studies to engineering degrees was noticed in an unpublished internal diagnosis study conducted over freshmen of this institution in 2000. Despite of the fact that freshmen had chosen engineering degrees in order to improve their social and professional status, it was reported important lacks of knowledge on the professional competences of the studies and the goals of the learning task. Other questions that freshmen have to face off in the first academic year were how to deal with academic problems, in particular with the practices of certain subjects. Finally, they also show lack of information about rules, bureaucracy, and facilities offered by the university to them.

At that time it was not necessary for a university to set a program that smoothed the transition from post-compulsory secondary education to university. It was expected that engineering studies had to be hard, and all these problems had to be solved by students on their own. However, as time went by, programs focused on smoothing transition have been considered and evaluated in the reports made by the Spanish Agency for Quality Evaluation and Accreditation (ANECA), in order to authorize the running of a degree in a Spanish university (ANECA, 2011).

To deal with these problems, the role of a mentor was proposed in order to optimize the formative process of freshmen, contributing in the personal, academic, and professional sides at the same time. This was pointed out some years before (Campbell \& Campbell, 1997; Kerry \& Mayes, 1995). Firstly, in 1999, two different programs of mentoring started: one with a teacher mentor and another with a senior student as a mentor. However, these programs were seen very soon during the first year to be complementary and that it would be more fruitful if both of them were integrated in a unique program. In this new program, it was expected that mentors belong to the same school as the corresponding 
freshmen. Even more, the teacher mentor was intended to be also his/her teacher in the first year, since it would help him/her to meet more frequently the mentees and to organize the meetings. This has been also considered up to now.

The new program was firstly conducted at the UPV in the academic year 2000/2001 at six schools of the UPV involving 700 freshmen and 200 teacher mentors. In this first year, every school was autonomous. However, they were supported by the technical staff of the Institute of Science Education (ICE) of the UPV. At the end of this edition, $92 \%$ of the teacher mentors reported it as very satisfactory, it was therefore decided to extend the program to all schools of UPV. In the last years, the program has attracted about one third of all new freshmen:

\begin{tabular}{|l|c|c|c|}
\hline & $2006 / 2007$ & $2007 / 2008$ & $2008 / 2009$ \\
\hline New freshmen at UPV & 4512 & 4401 & 4064 \\
\hline Mentees & $1284(28,45 \%)$ & $1628(36,99 \%)$ & $1446(35,58 \%)$ \\
\hline Student Mentors & 513 & 471 & 347 \\
\hline Teacher mentors & 305 & 287 & 335 \\
\hline
\end{tabular}

Table 1. "Participation in the PATU program in the period 2005-2009". Source: ICE-UPV.

\section{Characteristics of the PATU program}

After this pilot experience, our mentoring program was established as we indicate.

\subsection{Goals}

With minor changes from the beginning, the main goals set for this mentoring program are the following, see (García \& Cáceres, 2000):

- To support and guide students in their comprehensive training process.

- Identify difficulties related to the contents of the subjects, the teachers, the methodology, and the evaluation system, and discuss the solutions.

- Promote the use of academic mentoring.

- Avoid the feeling of isolation and loneliness of freshmen.

- Encourage the students to participate in the school.

- Promote the integration of new students in the school and in the university. 
- Develop the capacity for reflection, dialogue, autonomy, and criticism.

\subsection{Structure}

The general program is coordinated by a working group composed by a Vice-rector (nowadays the Vice-rector for Students' Affairs), the Head of the Academic Performance and Curricula Assessment Office, a Vice-Dean from each school acting as a local coordinator there, and the Head and technical staff of the ICE.

Local coordinators take care of the development of the program at their school. This includes, among other tasks, recruiting teachers and students to become mentors, introducing the program during the Welcome Days held at the school to the new freshmen, and the assignment of freshmen to mentors. The training of mentors does not depend on them, it lays on the technical staff of the ICE.

To help the local coordinators, a student at each school is granted with a scholarship. This student has some office hours to attend and solve the first doubts of mentees and student mentors. This student is also in charge of organizing the reports of mentees and mentors, both teachers and students. To accomplish these tasks, about 350-450 hours per year are needed, a bit less than an hour per new student. We point out that this is possible after having developed an application known as SELLA that is accessible for mentors and mentees through the intranet. It also helps them to organize meetings, control the participation of the mentees, keep a diary of the meetings, and to sum up contents treated in the meetings.

This application has not only improved the communication between mentors and mentees, but it has also reduced to halve the dedication of the granted students, local coordinators, and technical staff of the ICE. In addition, this application is very helpful in order to objectively assess the results of the program at the end of every academic course and to recognise the participation of everyone in the program.

\subsection{Teacher mentor's tasks}

Following (Rodríguez-Espinar, Alvarez-González, Echeverría, \& Marín, 1993) we consider that during a tutorship the mentor should offered him/herself to the mentees in order to help them in what they ask for. Therefore, mentoring 
combines functions of guidance, monitoring, and of info supplier. In order to do this, a teacher mentor is expected to carry out the following tasks:

- To facilitate the development of his/her learning skills and strategies, according to his/her own model of learning.

- Help the mentee to take advantage of an effective study time.

- Provide information about facilities of the university and activities organized at the school and promote the participation of the mentees in activities that improve his/her training.

- Follow up the academic performance of mentees and evaluate it with them.

- Identify problems that are interfering with the learning process of the student, and address the mentee to the corresponding services offered by the institution (Health Center, Psychopedagogical University Guidance Office, Career and Employment Office, etc.).

To conduct them, it is expected that mentors and mentees were expected to hold several meetings along the course. A $97.5 \%$ of the mentees have held between 5 and 10 meetings.

Finally, we point out that apart from the profit for mentees, mentoring helps teachers to know better their students and the subjects of other departments, and to develop other formative skills that are usually hidden in class.

\subsection{Student mentor's tasks}

As teacher mentors, they also contribute to help the mentee to take advantage of an effective study time, but in these cases the approach is different when explaining e.g. which are the most important parts to be considered in order to pass every subject. In addition, they provide notes on certain subjects and exams of previous years to the mentees. We point out that this information is only given from the point of view of the student mentor, but it can be very helpful to the mentee. One can expect that mentees take a lot of profit from student mentors, but most student mentors think the opposite. 
In return to the student mentors, most of them consider that these programs help them to learn how to manage groups. Besides, the program lets them to have a second thought on the curriculum of the degree and understand better the contents of the first academic course.

\subsection{Recognition for all participants}

Teachers participating in the PATU program were firstly granted with some symbolic amount of money to cover their own expenses such as teaching material or displacements to conferences. This participation is also acknowledged in the Teaching Activity Indicator (IAD). This inner indicator is fully recognized by the Spanish Agency for Quality Evaluation and Accreditation (ANECA).

Senior students acting as mentors receive up to 4 free election credits in their curricula. Additionally, most of schools at UPV offer up to 2 free election credits to mentees. In both cases, the number of credits assigned to every student is decided by the local coordinator from the number of meetings detailed at SELLA. Usually, all degrees have up to a $5 \%$ of free election credits included in the syllabus. These credits can be achieved in different ways, mainly from complementary tasks and actions. Participating in the program is recognized for the students as a complementary action granted with free election credits. In the UPV, all degrees adapted to the new European Higher Education Area (EHEA) are fully offered from the 2010-2011 academic year. These degrees, organized in four years, 240 ECTS, include up to 6 ECTS (European credits) that can be achieved from complementary tasks. Student mentors participating in the PATU program will receive up to 1 ECTS. The recognition for mentees has not been considered yet.

\subsection{Meetings}

Mentors tasks with mentees will be developed in three kinds of meetings:

a. Individual meetings: Every mentor will try to meet individually every mentee at least once, since some personal problems may not arise during group meetings. In some cases the mentor can help him/her; otherwise, he/she can always address him/her to the suitable aforementioned service.

b. Group meetings: Here, a pair of mentors meets their mentees, but in some cases two or three groups can meet all together at the same time. 
c. Follow up meetings: Every local coordinator organizes at least 3 follow up meetings with mentors to discuss the evolution of the program.

Further information concerning the contents of these meetings can be found at (Garcia \& Cáceres, 2000; Conejero et al., 2011).

\section{Evaluation of the PATU program}

To evaluate the program, the following activities were carried out: minutes of every meeting, follow up meetings of the local coordinator with mentors at every school, final reports of mentors and mentees, questionnaires filled by mentees and mentors, and follow up meetings of the coordinating group. As we have said in the introduction, we will report the results obtained from the questionnaires filled in May 2009 , before the period of examinations of June.

\subsection{Dedication to the PATU program}

We asked all participants to estimate the number of hours spent in the program.

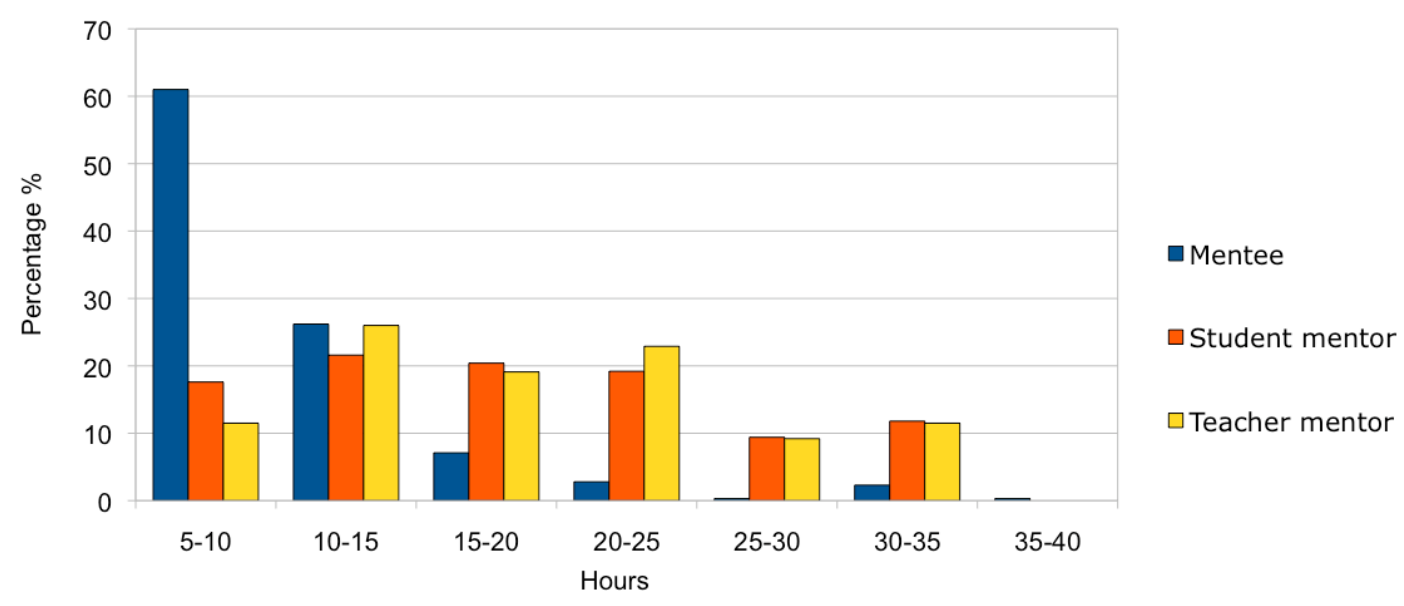

Figure 1. "Hours spent in the program".

As we can see in Figure 1 the number of hours spent by student and teacher mentors is similar. The average is 10.66 hours by mentees, 18.33 by student mentors, and 18.83 spent by teacher mentors. Despite of the fact that the dedication of both mentors is similar, their satisfaction with the program is different. 


\subsection{Fulfillment of participants expectations}

At first sight the results in Section 6.1 can be interpreted as a lack of interest in the PATU program by the mentees. However, the program is highly acknowledged by them, see Figure 2 .

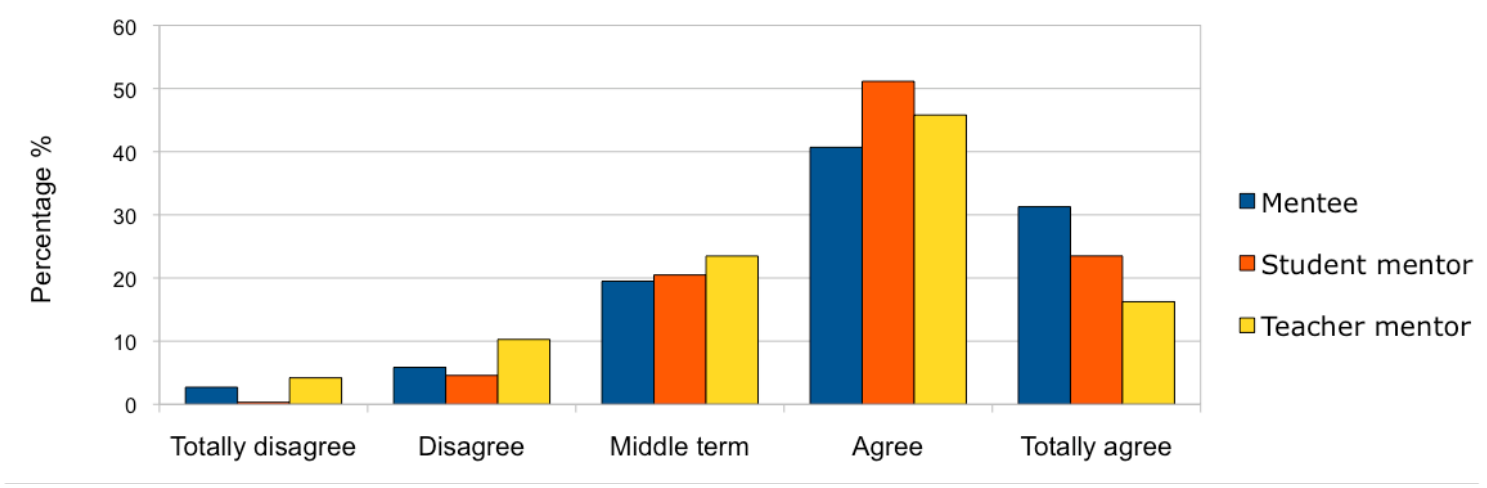

Figure 2. "Have the expectations on the program been fulfilled?".

In contrast to the results in Section 6.1, it is interesting to see that an accumulated average of the $71.97 \%$ of mentees have been satisfied with the program. The agreement rate for student mentors is even higher, $74.64 \%$. Nevertheless, only a $62.05 \%$ of the teacher mentors have meet their expectations with the program. We also analyze the satisfaction level of mentees asking them whether they will recommend a classmate to participate in it or not, and a $96 \%$ of them will do it.

\subsection{Mentors work in the meetings}

To deepen in the expectations on the program, we have asked to all actors participating in it, to evaluate the role of the mentors in the individual and group meetings. These data will show us how enthusiastic and how fruitful their participation in the program is. The role of a mentor was evaluated by his/her mentees and also by the other mentor. Firstly, in individual meetings, see Figure 3 , student mentors get a higher mark than teacher mentors. A $72.28 \%$ of the mentees consider that the student mentor participation can be considered as useful or even very useful. On the other hand, only a $61.29 \%$ of the mentees consider that the teacher mentor work was profitable. This can happen because mentees find the student mentor closer to them in age. 


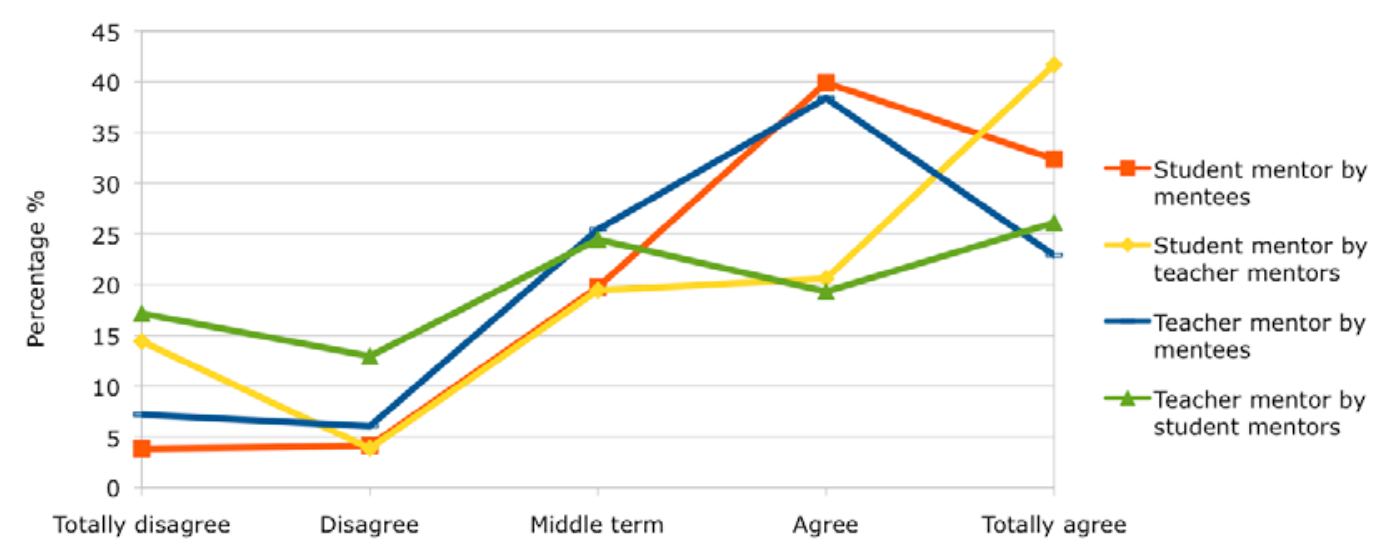

Figure 3. "Utility of the participation of mentors in the individual meetings".

But the results are still better for the student mentor in the group meetings, see Figure 4, where it should be expected that the teacher mentor would play a leading role since he/she can show a broader experience than the student mentor can. For group meetings, mentees are still more grateful to the student mentor, a $77.90 \%$ find their participation as useful. On the contrary, just a $68.15 \%$ of the mentees range the teacher mentor work as helpful.

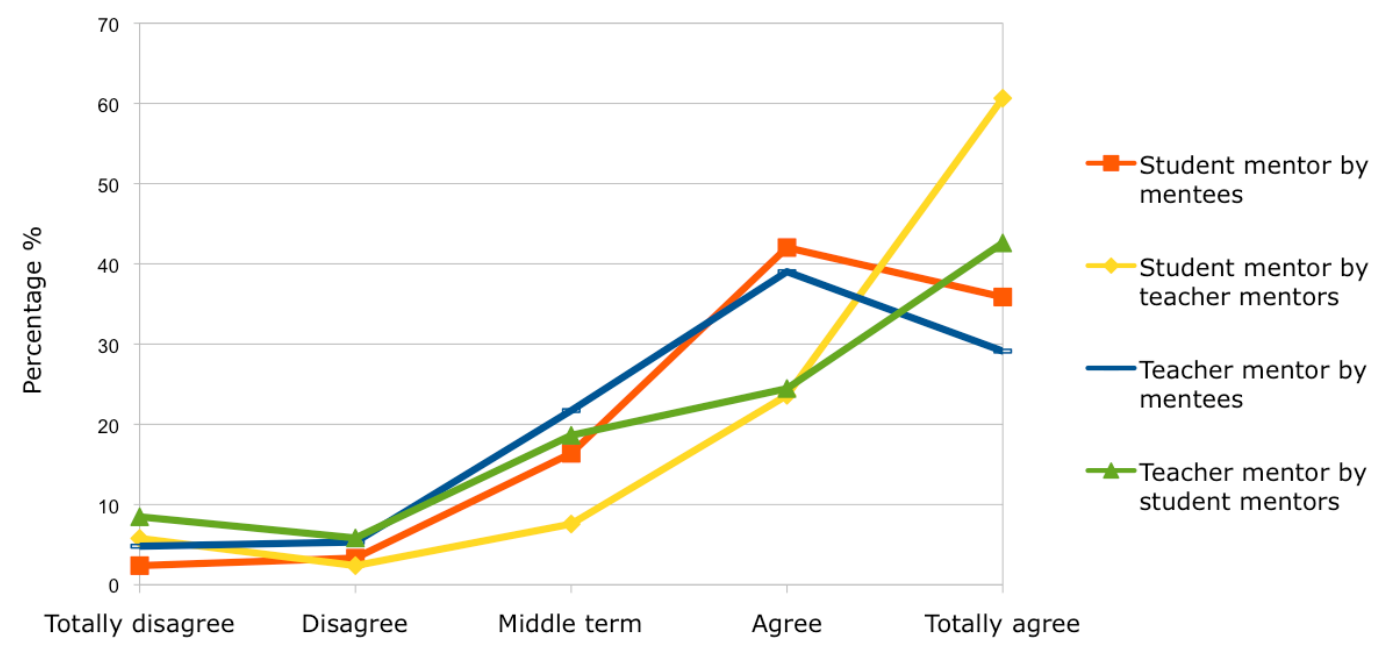

Figure 4. Utility of the collaboration of mentors during the group meetings.

\subsection{Development of the PATU program}

We also ask mentors and mentees about the goals of the program. We want to know if they were clear, if freshmen in general know them, and in the case of 
mentees, if they consider that they have been involved in the program. The answers to these questions can be seen at Table 2 . In this case the results are ranged from 0 to 10 . There is a general feeling among mentors that for many freshmen the program is not well known (item 2), and even in the case of their mentees, mentors think that their implication is lower than what mentees really think (item 3). Nevertheless, mentors and mentees consider that the goals are clear and adequate (item 1), and they have properly developed their tasks in the program (item 4), in a friendly atmosphere (item 5 ).

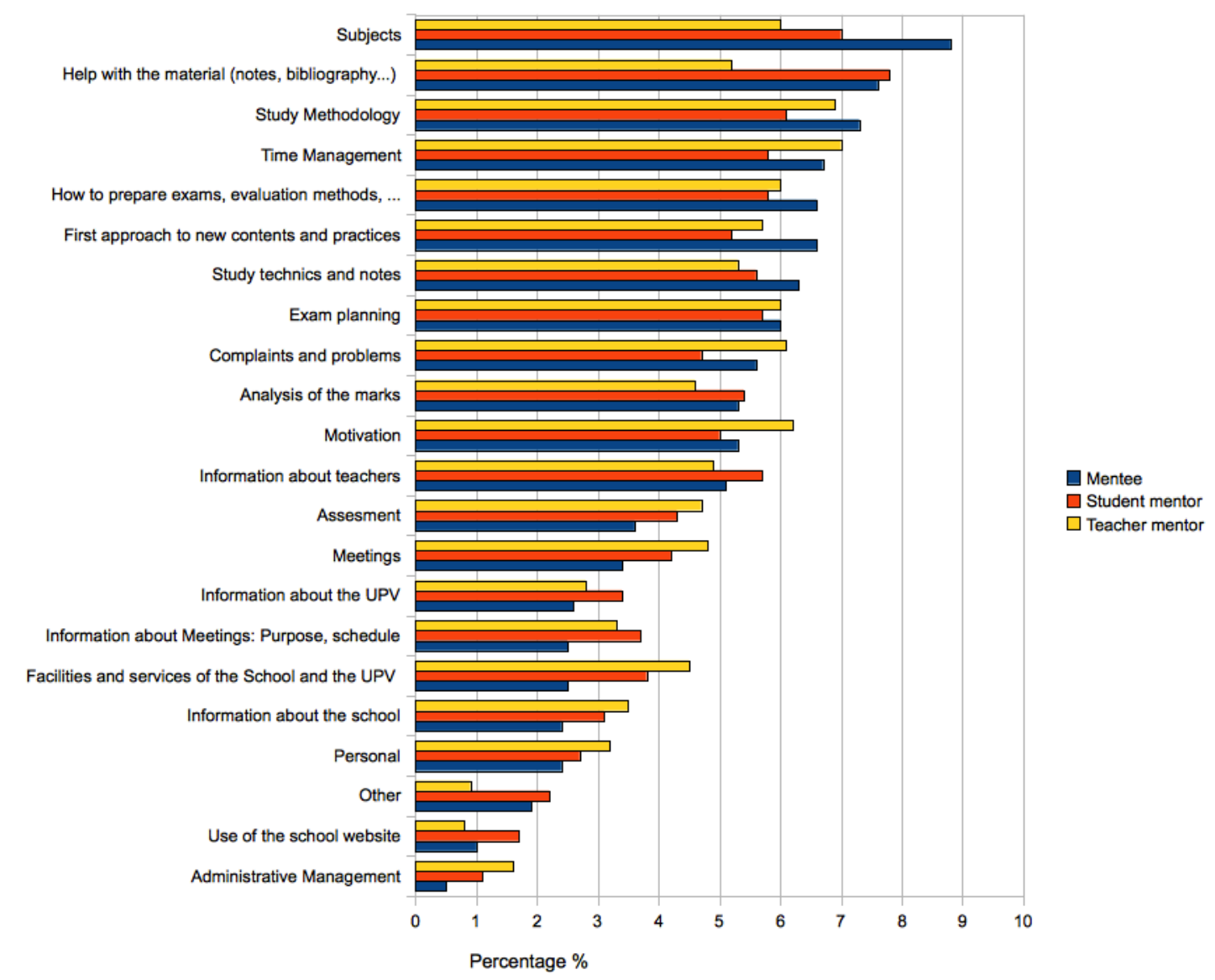

Figure 5. "Most interesting topics treated during the meetings"..

Finally, we ask mentees to say what were the most interesting or trending topics that were considered in the group meetings. The results are shown in Figure 5. We see that the most interesting ones are the subjects, their material, and study methods. What is also very interesting is that time management is also an important trend. This was also reported in (Capilla et al, 2010) when freshmen 
were asked at our university at the beginning of their first academic course what the most significative trend of engineering studies was.

\begin{tabular}{|l|c|c|c|}
\hline & $\begin{array}{c}\text { Mark given by } \\
\text { the mentee }\end{array}$ & $\begin{array}{c}\text { Mark given by the } \\
\text { student mentor }\end{array}$ & $\begin{array}{c}\text { Mark given by the } \\
\text { teacher mentor }\end{array}$ \\
\hline $\begin{array}{l}\text { 1. The goals of the program are clear } \\
\text { and adequate }\end{array}$ & 6.7 & 6.9 & 7 \\
\hline $\begin{array}{l}\text { 2. Freshmen know clearly what can } \\
\text { the mentoring program do to help } \\
\text { them }\end{array}$ & --- & 5.1 & 5.6 \\
\hline $\begin{array}{l}\text { 3. Degree of the implication of the } \\
\text { mentee }\end{array}$ & 7.1 & 6.3 & 6.3 \\
\hline $\begin{array}{l}\text { 4. The most important topics have } \\
\text { been treated clearly }\end{array}$ & 7.2 & 8.1 & 7.9 \\
\hline $\begin{array}{l}\text { 5. The ambience generated has been } \\
\text { positive and enriching }\end{array}$ & 8 & 8 & 8.2 \\
\hline
\end{tabular}

Table 2. "Agreement rate with the development of the PATU program".

\section{Conclusions}

To sum up, despite of the fact that the dedication of the mentee in the PATU program is not so high, since they usually participate in 5 or 10 meetings during the course and they dedicate between 10 to 15 hours to the program, they are satisfied with the program and they would highly recommend other freshmen to participate in it. In terms of ECTS, the recognition of 0.5 ECTS for the mentee and 1 ECTS for the student mentor would be enough. However, it would not heart to increase these quantities in order to make the participation in the program more attractive to the students. On the other hand, we consider that the teacher mentor was recognized with a similar amount of hours as the student mentor is.

On the other hand, the student mentor feels more enthusiastic with the program than the teacher mentor. In addition, he/she even thinks that mentees could take more profit from their participation. Finally, the teacher mentors have high expectations on the program that are not usually totally satisfied at the end of the course. Usually, all efforts on increasing the participation in the program are usually addressed to freshmen, but one wonders if encouraging teacher mentors in their task would be more fruitful.

\section{Acknowledgments}

We would like to acknowledge the participation of mentees, mentors, and local coordinators of the academic course 2009/2010. The PATU program is supported 
by the Vicerrectorado de Alumnado y Servicios al Estudiante of the Universitat Politècnica de València and by MEC "Ayuda para el Impulso e Implementación de Sistemas Tutoriales de Estudios de Grado".

\section{References}

Arco, J.L. (2010). Transiting the transition: Peer-tutoring as a catalist of the Bologna process. Presented at Fedora Psyche Conference. Alicante, Spain.

Arco, J.L., Heiborn, V., López, S., Fernández, F., Maroto, N., \& Recio, D. (2004). Memoria anual del curso 2003/2004 del Gabinete Psicopedagógico de la Universidad de Granada. Retrieved March, 15th, 2011, from http://www.ugr.es/ ve/gpp/files/memorias/MEMORIA_GPP_03-04.PDF

ANECA (Agencia Nacional de Evaluación de la Calidad y de la Acreditación)- (2011). Programa VERIFICA. Retrieved March, 15th, 2011, from http://www.aneca.es/Programas/VERIFICA

Boletín Oficial del Estado (2010). Real Decreto 1791/2010, de 30 de diciembre, por el que se aprueba el Estatuto del Estudiante Universitario. Retrieved March, 15th, 2011, from http://www.boe.es/boe/dias/2010/12/31/pdfs/BOE-A-2010-20147.pdf

Cambpell, T., \& Campbell, D.E. (1997). Faculty/Student Mentor Program: Effects on Academic Performance and Retention. Research in Higher Education, 38(6), 727-742.

\section{doi: $10.1023 / \mathrm{A}: 1024911904627$}

Capilla, R., Conejero, J.A., García, E., Rodríguez, C., \& Vivancos, V. (2010). University Choice: What do secondary school students need to know about a university that would facilitate their choice? Presented at Fedora Psyche Conference. Alicante, Spain.

Casado, R., \& Ruíz, M. (2009). Programa Mentor: Tutorías entre compañeros. Paper presented at UNIVEST 09. Presented at Claves para la Implicación de los Estudiantes en la Universidad. Girona, Spain.

Conejero, J.A., García-Félix, E., Vendrell, E. \& Vivancos, V. (2011). PATU: A mentoring program for freshmen. Proceedings of the IEEE EDUCON Education 
Engineering 2011 - Learning Environments and Ecosystems in Engineering Education. Amman, Jordan. 739-744. ISBN: 978-1-61284-641-5.

Ehrich, L.C., Hansford, B., \& Tennent, L. (2004). Formal mentoring programs in education and other professions: A review of the literature. Educational Administration Quarterly, 40, 518-540.

doi: $10.1177 / 0013161 \times 04267118$

García, P., \& Cáceres, P. (2000). El Plan de Acción Tutorial Universitario (PATU) en la UPV. Technical report. Ed. Universidad Politécnica de Valencia. Depósito Legal V-4326-2000.

Husband, P.A., \& Jacobs, P.A. (2009). Peer mentoring in Higher Education: A review of the current literature and recommendations for implementation of mentoring schemes. The Plymouth Student Scientist, 2, 228-241.

Kerry, T., \& Mayes, A.S. (1995). Issues on Mentoring. The Open UniversityRouyledge.

Marchena, E., Gómez, I., Alcalde, C., Aguilar, M., \& Navarro, J.I. (2005). Tutoría entre iguales en la Universidad de Cádiz: Proyecto compañero. Tavira: Revista de Ciencias de la Educación, 21, 197-204.

Pendleton, M. (2006). Student menetoring and peer tutoring: A literature review. Document. RMIT University.

Rodríguez-Espinar, S., Alvarez González, M., Echeverría, B., \& Marín, M.A. (1993). Teoría y Práctica de la Orientación Educativa. PPU: Barcelona.

Sánchez Ávila, C. (2009). Red de Mentoría en entornos universitarios: encuadre y objetivos. Mentoring and Coaching, 2, 11-25.

Sánchez, C., Almendra, A., \& Jiménez, F.J. (2007). Origen, desarrollo, evolución y resultados del proyecto Mentor en la ETSI de Telecomunicación de la Universidad Politécnica de Madrid. Red de Mentoría de Entornos Universitarios. Cuadernos de Innovación Educativa, 1, 35--46. 
Universidad Politécnica de Valencia. Vicerrectorado de Coordinación Académica y Alumnado (2001). Una Enseñanza Orientada al Aprendizaje. Retrieved March, 15th, 2011, from http://www.upv.es/europa/.

Valverde, A., García, E., \& Romero, S. (2001) La función tutorial en la Universidad de Sevilla. La mentoría como respuesta: El proyecto S.I.M.U.S.. Retrieved March, 15th, 2011, from http://www.redeseducacion. net/proyectosimus. htm.

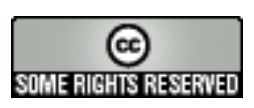

Article's contents are provided on a Attribution-Non Commercial 3.0 Creative commons license. Readers are allowed to copy, distribute and communicate article's contents, provided the author's and Journal of Industrial Engineering and Management's names are included. It must not b0e used for commercial purposes. To see the complete license contents, please visit http://creativecommons.org/licenses/by-nc/3.0/. 